\author{
Stanislava Spinková \\ Ústav pro jazyk český AV ČR, v. v. i. \\ Dialektologické oddělení \\ Brno \\ ORCID: 0000-0002-6024-626X; e-mail: spinkova@ujc.cas.cz
}

\title{
PhDr. Stanislava Kloferová, CSc. 3.11.1955 - 5.07.2020
}

V létě tohoto roku jsme se rozloučili s PhDr. Stanislavou Kloferovou, CSc. (*3.11.1955 - † 5.07.2020), významnou českou lingvistkou, bohemistkou a lexikografkou; a také dobrým a laskavým člověkem. V lingvistice se specializovala na oblast dialektologie, na jazykový kontakt (zvláště česko-německý) a v posledních letech se věnovala také toponomastice. Patřila též mezi důvtipné popularizátory lingvistiky.

Stanislava Kloferová vystudovala v letech 1974-1979 obory německý jazyk a literatura a český jazyk a literatura na Filozofické fakultě tehdejší Univerzity Jana Evangelisty Purkyně v Brně. Po většinu svého aktivního života (v letech 1982-2000 a 2002-2020) pracovala v dialektologickém oddělení Ústavu pro jazyk český Československé akademie věd (později Akademie věd České republiky) v Brně. V letech 1993-2000 byla vedoucí dialektologického oddělení. V letech 2000-2002 působila v Institutu für Slawistik der Universität Wien v Rakousku. V letech 1983-2019 spolupracovala také externě s Filozofickou fakultou brněnské univerzity (do r. 1990 Univerzita Jana Evangelisty Purkyně, od r. 1990 Masarykova univerzita, Brno) - byla oblíbenou učitelkou v Kabinetu češtiny pro cizince a v Ústavu českého jazyka FF MU. Od r. 1983 vyučovala $\mathrm{v}$ kurzech češtiny pro cizince, dále od r. 1990 vedla též semináře a přednášky pro české studenty z morfologie současné češtiny, z tvoření slov v současné češtině a $\mathrm{z}$ dialektologie; pomáhala také studentům při psaní diplomových, resp. disertačních prací z oboru dialektologie. Dále spolupracovala s Ústavem českého jazyka Filozofické fakulty Masarykovy univerzity na projektech Encyklopedický slovník češtiny (2002), Kapitoly z dějin jazykovědné bohemistiky (2007) a Nový encyklopedický slovnik češtiny (2016; též online <https://czechency.org>).

V centru badatelského zájmu Stanislavy Kloferové byl výzkum mluveného jazyka v jeho geografické diferenciaci. Její disertační práce Jazyková situace v nově dosídleném severomoravském pohraniči byla pro svou metodologickou vyspělost v roce 1991 vyznamenána cenou Českého literárního fondu. Přepracovaná verze této práce byla publikována roku 2000 jako knižní monografie pod názvem Mluva v severomoravském 


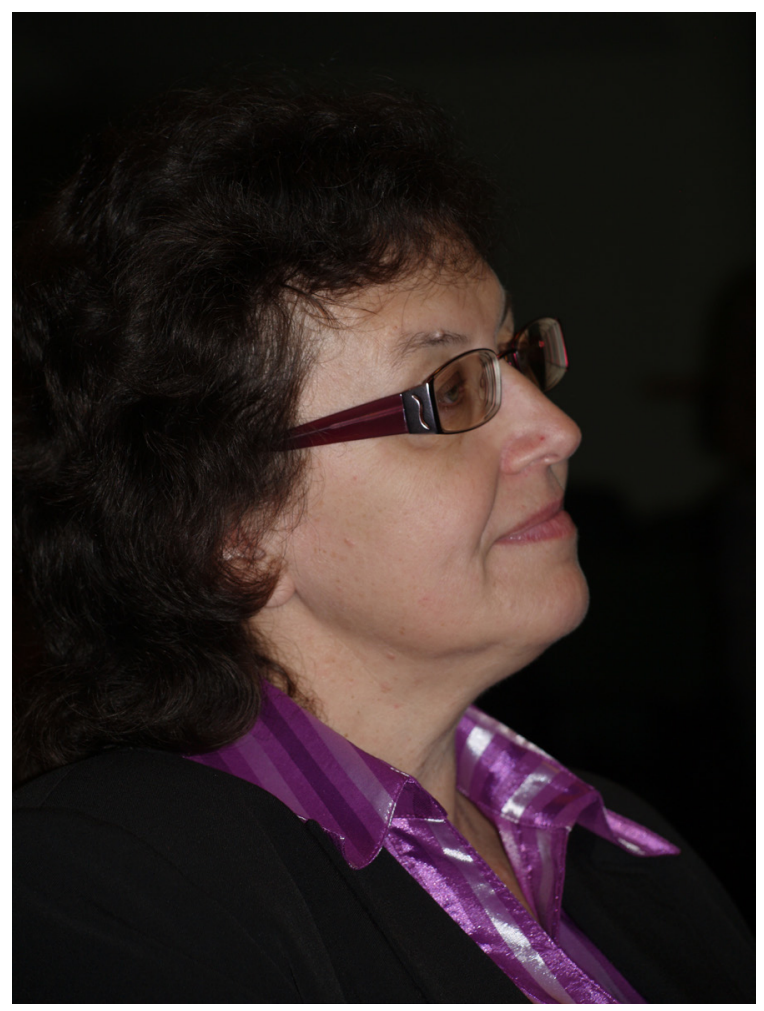

Fot. 1. Stanislava Kloferová - Obrzycko - 2010 r. (fot. J. Sierociuk)

pohraničí. Byla v ní postižena specifická jazyková situace v pohraničí někdejšího Severomoravského kraje, z větší části tedy v české části Slezska.

Stanislava Kloferová byla důležitou členkou velkých kolektivních dialektologických projektů, a to šestisvazkového Českého jazykového atlasu (1-5, Dodatky, 1992-2011, dílo je od r. 2014 dostupné též online na $<$ http://cja.ujc.cas.cz $>$ a $<$ https://cja.ujc.cas. cz/e-cja>, za podpory výzkumné infrastruktury LINDAT/CLARIAH-CZ, https://indat. cz, podporované Ministerstvem školství, mládeže a tělovýchovy České republiky, projekt č. LM2018101) a elektronicky realizovaného Slovníku nářeči českého jazyka (online na <http://sncj.ujc.cas.cz>, 2016-). Zvláště přínosné a objevné bylo vypracování kapitoly Svazky izoglos v nářečich publikované v pátém svazku Českého jazykového atlasu (2005). Zásadním způsobem se pak podílela na tvorbě koncepce Slovníku nářeči českého jazyka a do budoucna bude při jeho sestavování velmi chybět.

Častým tématem studií z pera Stanislavy Kloferové jsou dialektové fenomény v jazykovém kontaktu, zejména ve styku češtiny s němčinou. $\mathrm{V}$ devadesátých letech se také zúčastnila mezinárodních projektů Česko-rakouské jazykové kontakty (s Institutem für Österreichische Dialekt- und Namenlexika der ÖAW) a Mluva vídeňských 


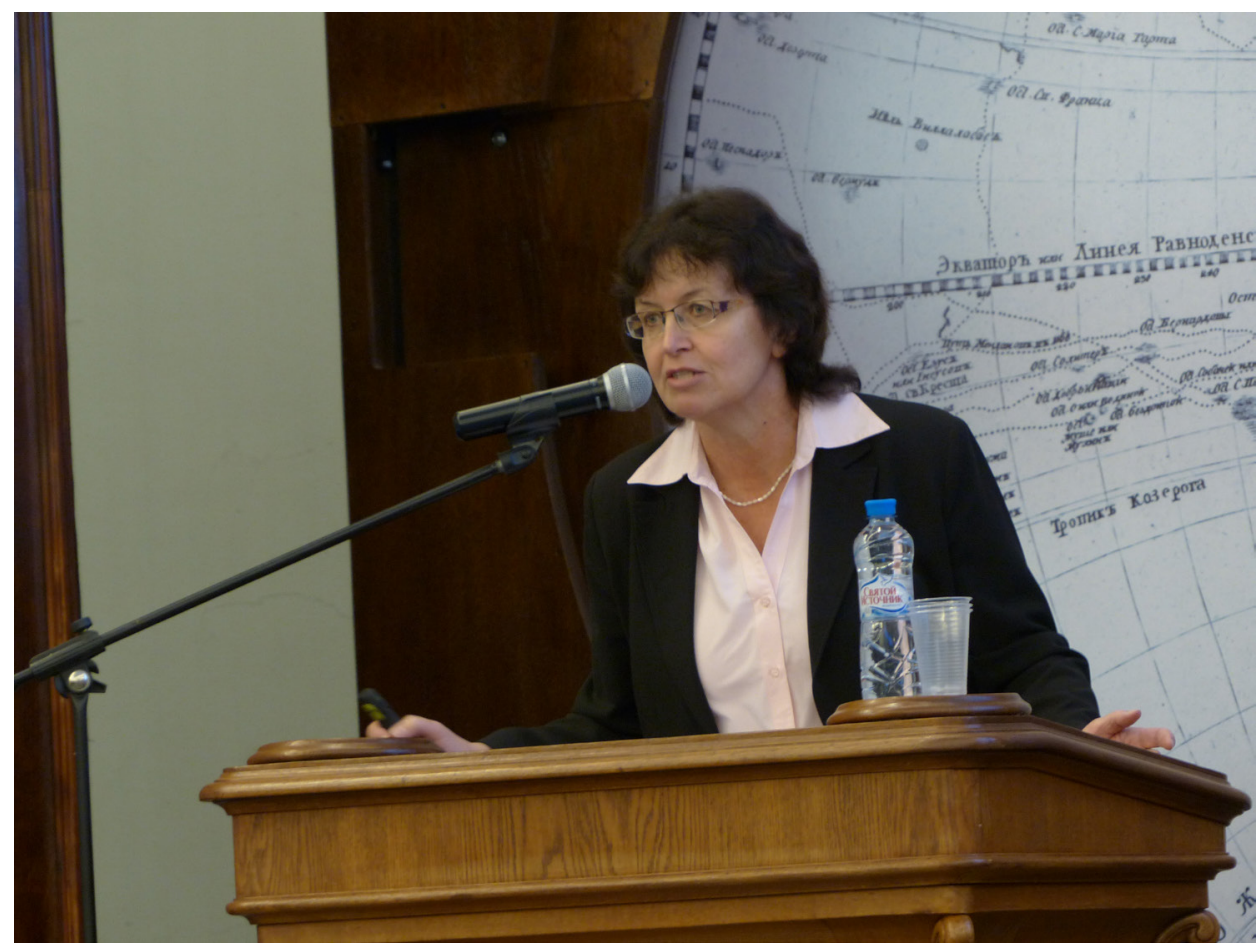

Fot. 2. Petersburg 2014 r. (fot. $\mathrm{z}$ archiwum Pracowni Dialektologicznej UAM)

Čechů (s Institutem für Slawistik der Universität Wien). Lze říci, že důležitý byl pro dr. Kloferovou studijní pobyt v Institutu für deutsche Sprache, Deutscher Sprachatlas, v Marburgu v Hessensku na podzim roku 1996 a také kontakt s dalšími pracovišti v Německu, např. s Institutem für Germanistik der Justus-Liebig-Universität v Gießenu.

Neslovanský jazykovědný svět informovala o poměrně rozsáhlém a propracovaném využívání jazykovězeměpisných metod při zpracovávání jazykového materiálu ve slovanských zemích, a to v kapitole Mapping the Slavic languages v dvousvazkové př́iručce Language and Space. An International Handbook of Linguistic Variation. Volume 2. Language Mapping (2010).

Už od osmdesátých let se Stanislava Kloferová zabývala v několika článcích také onomastickou problematikou. Od roku 2005 se pak onymickému materiálu věnovala intenzivněji - podílela se totiž na obnoveném projektu dialektologického oddělení Ústavu pro jazyk český AV ČR, v. v. i., na budování Slovniku pomistních jmen na Moravě a ve Slezsku. Účastnila se vytváření elektronické databáze i tvorby slovníkových hesel; ta jsou od r. 2014 zveřejňována online na <http://spjms.ujc.cas.cz>.

Ve svých toponomastických publikacích se dr. Kloferová zaměřovala zvláště na tato tři témata: pomístní jména utvořená sufixací od osobních jmen, lidovou etymologii a porovnávání onymických a apelativních areálů. Např. ve studii $K$ územnímu rozrůznění predložek v pomistnich jménech na Moravě a ve Slezsku uveřejněném v r. 2011 


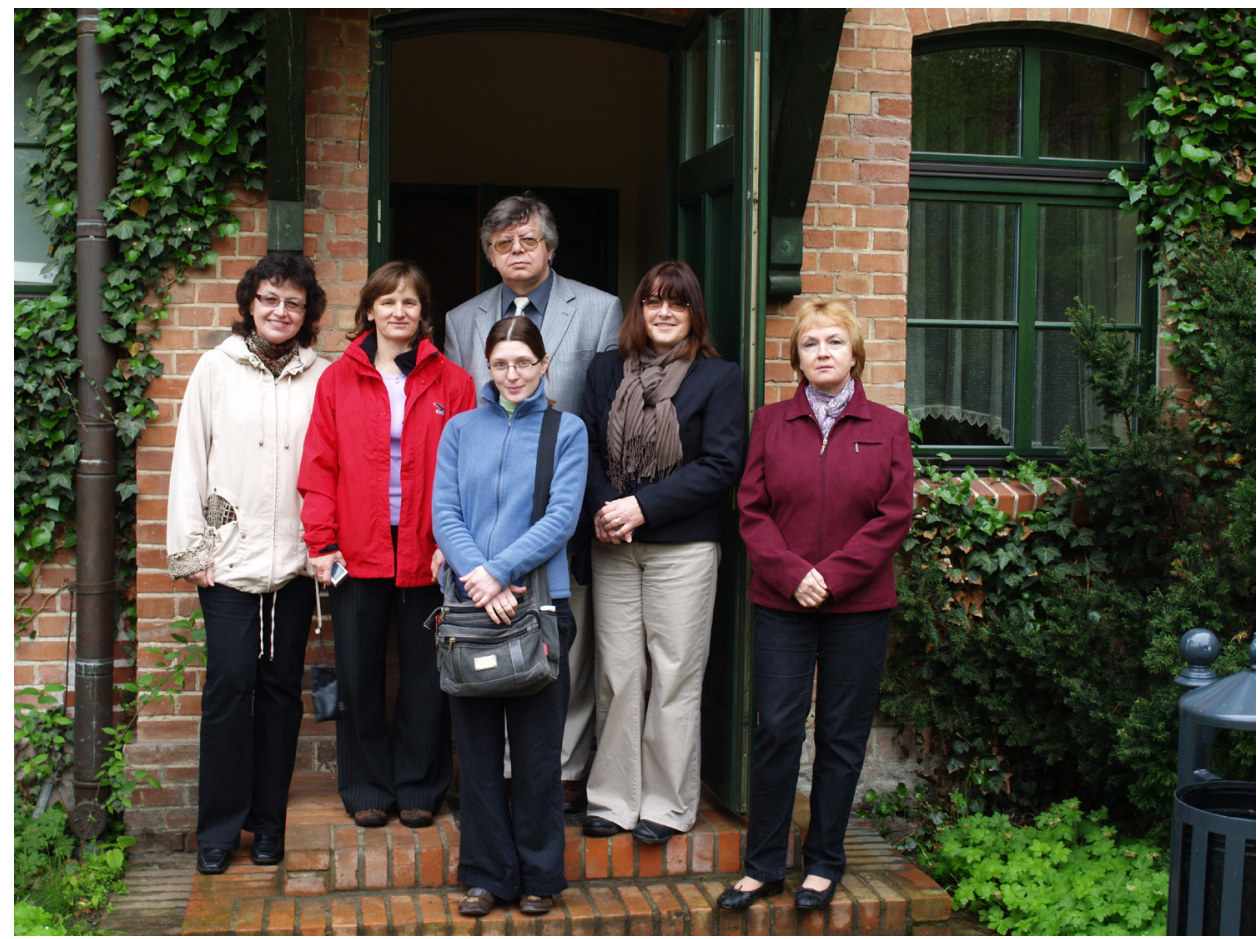

Fot. 3. Obrzycko - 2010 r. (fot. z archiwum Pracowni Dialektologicznej UAM)

v časopise „Acta onomastica” na specifickou distribuci některých prepozic $\mathrm{v}$ české část Slezska (jde o prepozice $k u$ a při $\mathrm{v}$ anoikonymickém použití).

Stanislava Kloferová opustila náš svět předčasně, svých 65. narozenin už se nedožila. Odešla uprostřed práce, na vrcholu svých tvůrčích sil. Za její odchod může smůla, řetězec nešt’astných událostí, které následovaly po banálním úrazu. Její odchod trval bohužel skoro celý rok, protože před úrazem byla zcela zdravá. Byla velmi milým a veselým člověkem, člověkem vlídným. Byla štastná ve své rodině a po celý život i ve své dialektologii.

Její kompletní bibliografie bude publikována ve 2. čísle časopisu Linguistica Brunensia (ročník 68, 2020, s. 93-103; <https://doi.org/10.5817/LB2020-2-1>). Časopis je publikován též online, viz <https://www.phil.muni.cz/journals/index.php/linguistica -brunensia>. 